\title{
EVALUATION OF THE ANTI-INFLAMMATORY ACTIVITY OF COMBINATION OF ETHANOL EXTRACTS OF AZADIRACHTA INDICA (NEEM) AND LAWSONIA INERMIS (HENNA)
}

\author{
TIRUPATHI RAO ANNAVARAPU*, RENUKA P, AKHIL P, DIVYA P, DEVI PRIYANKA P
}

Department of Pharmacology, Aditya Pharmacy College, Surampalem, East Godavari, Andhra Pradesh, India. Email: tirupathionline@gmail.com

Received: 14 June 2016, Revised and Accepted: 16 June 2016

\section{ABSTRACT}

Objective: The aim of the present study was to investigate the in vitro anti-inflammatory activity of Azadirachta indica (neem) and Lawsonia inermis (henna) individual extract and in combination using the same solvent.

Methods: The leaf material of $A$. indica and L. inermis was collected from surroundings of Aditya College of Pharmacy, Kakinada, East Godavari. Powdered material was subjected to successive solvent extraction process. The yield was collected and prepared different concentrations $(50,100$ and $200 \mu \mathrm{g} / \mathrm{ml}$ ) of plant extracts. Diclofenac sodium was used as standard drug. The anti-inflammatory activity was performed by in vitro methods such as albumin denaturation method and human red blood cells membrane lysis method.

Results: Denaturation of proteins is a well-documented cause of inflammation. Neem showed a significant membrane stabilizing activity of $46.62 \%$ and protein denaturation inhibition activity of $57.32 \%$ at concentration of $200 \mu \mathrm{g} / \mathrm{ml}$. Henna showed a significant membrane stabilizing activity of $39.89 \%$ and protein denaturation inhibition activity of $53.75 \%$ at $200 \mu \mathrm{g} / \mathrm{ml}$. In combination, both the extracts showed a significant membrane stabilizing activity of $56.63 \%$ and protein denaturation inhibition activity of $67.69 \%$ at concentration of $200 \mu \mathrm{g} / \mathrm{ml}$.

Conclusion: The present study concluded that combination of $A$. indica and $L$. inermis possesses significant anti-inflammatory activity when compared with individual extract.

Keywords: Anti-inflammatory, Human red blood cell, Protein denaturation, Lawsonia inermis, Azadiracta indica.

(C) 2016 The Authors. Published by Innovare Academic Sciences Pvt Ltd. This is an open access article under the CC BY license (http://creativecommons. org/licenses/by/4. 0/) DOI: http://dx.doi.org/10.22159/ajpcr.2016.v9i5.13112

\section{INTRODUCTION}

Inflammation is a normal protective response to tissue injury, and it involves a complex array of enzyme activation, mediator release, fluid extravasations, cell migration, tissue breakdown, and repair [1] When cells in the body are damaged by microbes, physical agents or chemical agents, the injury is in the form of stress. Symptoms of inflammation include redness, swelling and pain, joint stiffness, loss of joint function as a result of infection, irritation, or injury. Plants may become the base for the development of a new medicine, or they may be used as phytomedicine for the treatment of disease [2]. In this growing interest, many of the phytochemical bioactive compounds from medicinal plants have shown many pharmacological activities [3]. Most of the anti-inflammatory drugs available in the market, having a wide range of problems such as efficacy and undesired effects including gastrointestinal tract disorders and other unwanted effects, gastrointestinal disturbances, renal damages, respiratory depression [4]. This situation highlights the need for advent of safe, novel, and effective analgesic and anti-inflammatory compounds [5].

\section{METHODS}

\section{Collection of plant material}

The leaf material of Azadirachta indica and Lawsonia inermis was collected from surroundings of Aditya College of Pharmacy, Kakinada, East Godavari.

\section{Preparation of extract}

The plant materials were dried under the shade and ground to fine powder with the help of electrical grinder. The dried powder of leaves of $A$. indica and L. inermis was subjected to maceration separately using ethanol for 5 days with intermittent shaking. After 7 days of maceration, the solvents mixture is filtered separately with the help of Whatman
No.1 filter paper. The obtained filtrates are subjected to distillation. The extracts thus obtained are then dried used in the present study.

\section{Assessment of in vitro anti-inflammatory activity} Inhibition of protein denaturation

The anti-inflammatory activity of leaf extracts $A$. indica and $L$. inermis was studied using inhibition of albumin denaturation which was studied according to Mizushima and Kobayashi [6] and Sakat et al. [7] followed with minor modifications. Test solution $(0.5 \mathrm{ml})$ consists of $0.45 \mathrm{ml}$ of bovine serum albumin ( $5 \% \mathrm{w} / \mathrm{v}$ aqueous solution) and $0.05 \mathrm{ml}$ plant extract (separately) in suitable solvent of different concentrations $(50,100$, and $200 \mu \mathrm{g} / \mathrm{ml})$. Test control solution $(0.5 \mathrm{ml})$ consists of $0.45 \mathrm{ml}$ of bovine serum albumin ( $5 \% \mathrm{w} / \mathrm{v}$ aqueous solution) and $0.05 \mathrm{ml}$ of distilled water. Product control solution $(0.5 \mathrm{ml})$ consists of $0.45 \mathrm{ml}$ of distilled water and $0.05 \mathrm{ml}$ of plant extract in suitable solvent of different concentrations $(50,100$, and $200 \mu \mathrm{g} / \mathrm{ml})$. Standard solution $(0.5 \mathrm{ml})$ consists of $0.45 \mathrm{ml}$ of bovine serum albumin $(5 \% \mathrm{w} / \mathrm{v}$ aqueous solution) and $0.05 \mathrm{ml}$ of different concentrations $(50,100$, and $200 \mu \mathrm{g} / \mathrm{ml}$ ) of diclofenac sodium. All the above solutions were adjusted to $\mathrm{pH} 6.3$ using $1 \mathrm{~N}$ hydrochloric acid. The samples were incubated at $37^{\circ} \mathrm{C}$ for 20 minutes, and the temperature was increased to keep the samples at $57^{\circ} \mathrm{C}$ for 3 minutes. After cooling, $2.5 \mathrm{ml}$ of phosphate buffer was added to the above solutions. The absorbance was measured using ultraviolet-visible spectrophotometer at $416 \mathrm{~nm}$. The percentage inhibition of protein denaturation was calculated as:

Percentage inhibition $=($ Abs control - Abs sample $) \times 100 /$ Abs control

\section{Membrane stabilization}

The principle concerned in this method is stabilization of human red blood cell membrane by hypotonicity-induced membrane lysis. Blood was collected $(2 \mathrm{ml})$ from healthy volunteers and was mixed with equal volume of sterilized Alsever's solution (2\% dextrose, $0.8 \%$ 
Table 1: In vitro anti-inflammatory activity of neem

\begin{tabular}{llll}
\hline Treatment & $\begin{array}{l}\text { Concentration } \\
(\boldsymbol{\mu g} / \mathbf{m})\end{array}$ & $\begin{array}{l}\text { Percentage } \\
\text { Inhibition } \\
\text { of protein } \\
\text { denaturation }\end{array}$ & $\begin{array}{l}\text { Percentage } \\
\text { of membrane } \\
\text { stabilization }\end{array}$ \\
\hline Neem extract & 50 & 32.02 & 21.30 \\
& 100 & 47.21 & 32.45 \\
Diclofenac & 200 & 57.32 & 46.62 \\
sodium & 50 & 94.62 & 73.43 \\
& 100 & 96.97 & 82.14 \\
& 200 & 99.03 & 90.40 \\
\hline
\end{tabular}

Table 2: In vitro anti-inflammatory activity of henna

\begin{tabular}{llll}
\hline Treatment & $\begin{array}{l}\text { Concentration } \\
(\boldsymbol{\mu g} / \mathbf{m l})\end{array}$ & $\begin{array}{l}\text { Percentage } \\
\text { of protein } \\
\text { denaturation }\end{array}$ & $\begin{array}{l}\text { Percentage } \\
\text { of membrane } \\
\text { stabilization }\end{array}$ \\
\hline $\begin{array}{l}\text { Henna } \\
\text { extract }\end{array}$ & 50 & 26.01 & 19.78 \\
& 100 & 38.42 & 24.60 \\
Diclofenac & 200 & 53.75 & 39.89 \\
sodium & 50 & 94.62 & 73.43 \\
& 100 & 98.97 & 82.14 \\
& 200 & 99.03 & 90.40 \\
\hline
\end{tabular}

Table 3: In vitro anti-inflammatory activity of neem and henna

\begin{tabular}{llll}
\hline Treatment & $\begin{array}{l}\text { Concentration } \\
(\boldsymbol{\mu g} / \mathbf{m l})\end{array}$ & $\begin{array}{l}\text { Percentage } \\
\text { of protein } \\
\text { denaturation }\end{array}$ & $\begin{array}{l}\text { Percentage } \\
\text { of membrane } \\
\text { stabilization }\end{array}$ \\
\hline $\begin{array}{l}\text { Neem and } \\
\text { henna }\end{array}$ & 50 & 34.34 & 22.45 \\
& 100 & 52.12 & 49.42 \\
& 200 & 67.69 & 56.63 \\
$\begin{array}{l}\text { Diclofenac } \\
\text { sodium }\end{array}$ & 50 & 94.62 & 76.05 \\
& 100 & 98.97 & 82.14 \\
& 200 & 99.03 & 90.40 \\
\hline
\end{tabular}

sodium citrate, $0.5 \%$ citric acid, and $0.42 \% \mathrm{NaCl}$ in distilled water) and centrifuged at $3000 \mathrm{rpm}$. The packed cells were washed with isosaline solution, and a $10 \% \mathrm{v} / \mathrm{v}$ suspension was prepared with normal saline. Different concentrations of each plant extract and in combination (50, $100,200 \mu \mathrm{g} / \mathrm{ml}$ ), diclofenac sodium $(50,100,200 \mu \mathrm{g} / \mathrm{ml})$ as standard and control (distilled water instead of hyposaline to produce $100 \%$ hemolysis) were separately mixed with $1 \mathrm{ml}$ of phosphate buffer, $2 \mathrm{ml}$ hyposaline solution, and $0.5 \mathrm{ml}$ of $10 \%$ human red blood cell (HRBC) suspension was added to prepared reaction mixture. All the assay mixtures were incubated at $37^{\circ} \mathrm{C}$ for 30 minutes and centrifuged at $3000 \mathrm{rpm}$ for 20 minutes, and hemoglobin content of the supernatant solution was estimated spectrophotometrically at $560 \mathrm{~nm}$ [8]. The percentage of HRBC membrane stabilization or protection was calculated using the formula:

Percentage inhibition $=($ Abs control - Abs sample $) \times 100 /$ Abs control

\section{RESULTS}

The ethanol extracts of the leaves of A. indica and L. inermis was studied for anti-inflammatory activity by protein denaturation and HRBC membrane stabilization. The anti inflammatory activity is concentration dependent, with increase in concentration the activity also increases. The anti inflammatory activity of ethanol extract of neem with reference to diclofenac sodium was illustrated in (fig. 1 and fig. 2). The percentage of inhibition of protein denaturation and percentage of

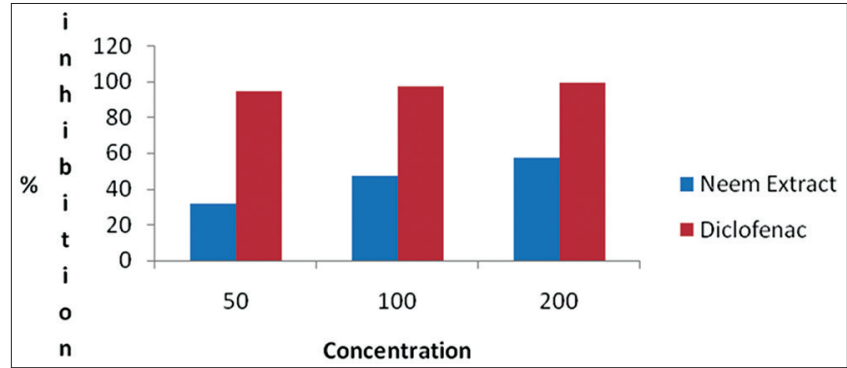

Fig. 1: Percentage inhibition of neem by protein denaturation

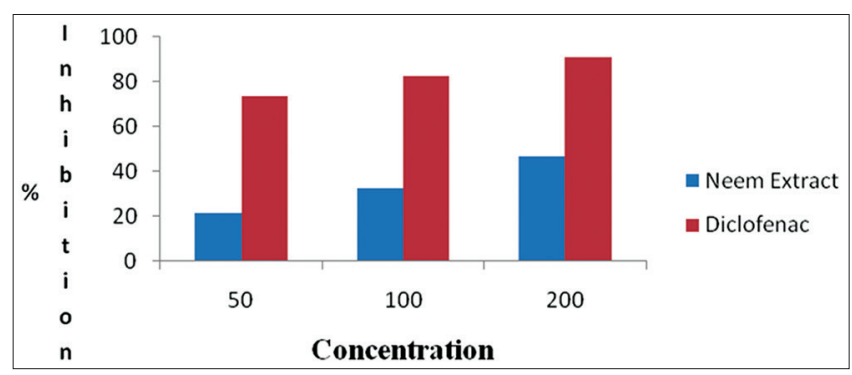

Fig. 2: Percentage inhibition of neem by membrane stabilization

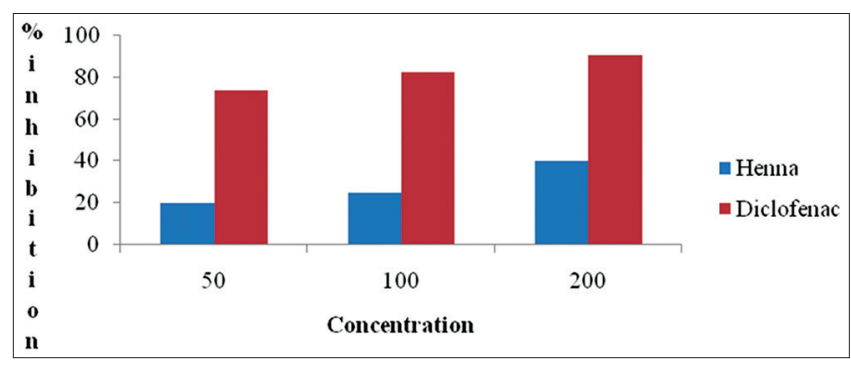

Fig. 3: Percentage inhibition by henna by membrane stabilization

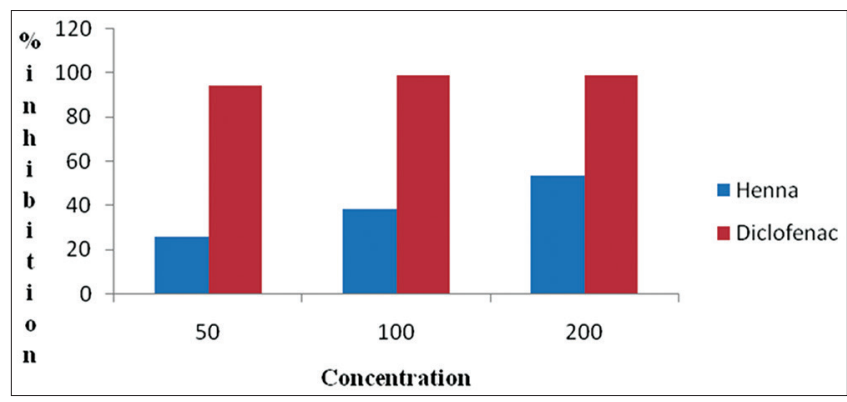

Fig. 4: Percentage inhibition of henna by protein denaturation

membrane stabilization for ethanolic extracts and Diclofenac sodium were done at 50, 100 and $200 \mu \mathrm{g} / \mathrm{ml}$. It shows anti inflammatory activity at concentration $200 \mu \mathrm{g} / \mathrm{ml}$ shows $57.32 \%$ ( inhibit protein denaturation) and $46.62 \%$ (protection membrane stabilization).

From the Table 2, the ethanolic extract of henna shows antiinflammatory activity at concentration of $200 \mu \mathrm{g} / \mathrm{ml}$ shows $53.75 \%$ (inhibition of protein denaturation) and 39.89\% (protection membrane stabilization). With the increasing concentration protein denaturation is decreased as shown in Fig. 4 and membrane stabilization/protection is increased as shown in Fig. 3.

Combination of ethanolic extracts of neem and henna was studied for anti-inflammatory activity and it shows increased activity at $200 \mu \mathrm{g} / \mathrm{ml}$ is $67.69 \%$ (inhibition of protein denaturation method) and $56.63 \%$ (membrane stabilization method) illustrated in Fig. 5 and Fig. 6. 


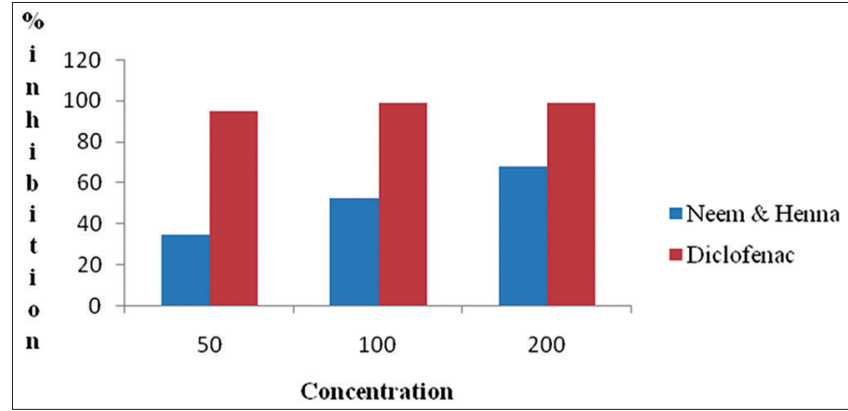

Fig. 5: Percentage inhibition of neem and henna by protein denaturation

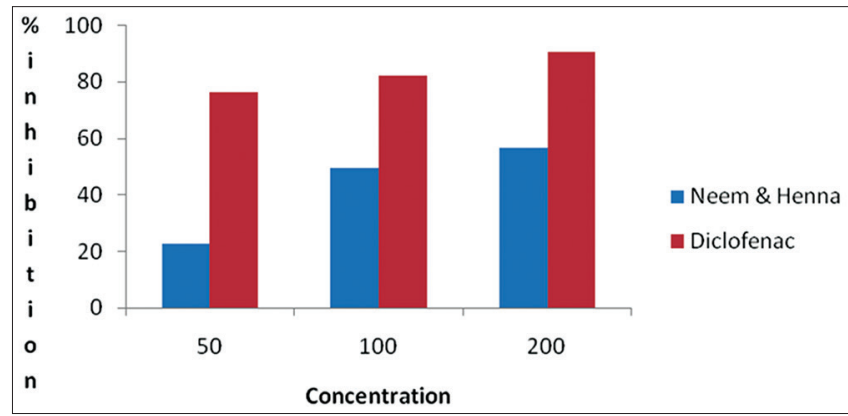

Fig. 6: Percentage inhibition of neem and henna by membrane stabilization

\section{DISCUSSION}

From the results, it is concluded that the combination of ethanolic extracts of neem (A. indica) and henna( $L$. inermis) possess greater anti inflammatory activity than individual plant extract. Here, the antiinflammatory activity was assessed by in vitro screening methods such as protein denaturation and HRBC method. Denaturation of proteins is a well-documented cause of inflammation. Most biological proteins lose their biological functions when denatured, and production of autoantigen in certain arthritic disease is due to denaturation of the protein [9]. The mechanism of denaturation involves alteration in electrostatic hydrogen, hydrophobic, and disulfide bonding [10]. The inhibition of protein denaturation with neem extract was $57.32 \%$, with henna extract was $53.75 \%$, and in combination was $67.69 \%$ at a concentration of $200 \mu \mathrm{g} / \mathrm{ml}$. During inflammation, lysosomal hydrolytic enzymes are released which causes damages of the surrounding organelles and tissues with variety of disorders. The erythrocyte membrane is analogous to the lysosomal membrane, [11] and its stabilization implies that the extract may as well stabilize lysosomal membrane. Stabilization of lysosomal membrane is important in limiting the inflammatory response by preventing the release of lysosomal constituents of activated neutrophil such as bactericidal enzymes and proteases which cause further tissue inflammation and damage upon extracellular release [12]. It is reported that the ethanolic extract of $A$. indica showed $46.62 \%$ and L. inermis showed $39.89 \%$, and in combination, it showed $56.63 \%$ protection at a concentration of $200 \mu \mathrm{g} / \mathrm{ml}$.

\section{CONCLUSION}

In the present investigation, the results indicate that the ethanolic leaf extracts of $A$. indica and $L$. inermis possess anti-inflammatory activity properties. The protective effect against protein denaturation and membrane stabilization is known to be a good index of antiinflammatory activity. From the present study, it is concluded that combination of $A$. indica and $L$. inermis possesses the highest antiinflammatory activity when compared with individual extract.

\section{ACKNOWLEDGMENT}

Authors are thankful to the Management and Principals of Aditya Group of Pharmacy Colleges, for providing the facilities required for the accomplishment of the research work.

\section{REFERENCES}

1. Vane JR, Botting RM. New insights into the mode of action of antiinflammatory drugs. Inflamm Res 1995;44(1):1-10.

2. Iwu MW, Duncan AR, Okunji CO. New antimalarials of plant origin. In: Janick J, editor. Perspective on New Crops and New Uses. Alexandria, VA: ASHS Press; 1999. p. 457-62.

3. Chen IN, Chang CC, Ng CC, Wang CY, Shyu YT, Chang TL. Antioxidant and antimicrobial activity of Zingiberaceae plants in Taiwan. Plant Foods Hum Nutr 2008;63(1):15-20.

4. Heidari MR, Mehrabani M, Pardakhty A, Khazaeli P, Zahedi MJ, Yakhchali M, et al. The analgesic effect of Tribulus terrestris extract and comparison of gastric ulcerogenicity of the extract with indomethacine in animal experiments. Ann N Y Acad Sci 2007;1095:418-27.

5. Kolesnikov Y, Sõritsa D. Analgesic synergy between topical opioids and topical non-steroidal anti-inflammatory drugs in the mouse model of thermal pain. Eur J Pharmacol 2008;579(1-3):126-33.

6. Mizushima Y, Kobayashi M. Interaction of anti-inflammatory drugs with serum proteins, especially with some biologically active proteins. J Pharm Pharmacol 1968;20(3):169-73.

7. Sakat S, Juvekar AR, Gambhire MN. In vitro antioxidant and inflammatory activity of methanol extract of Oxalis corniculata Linn. Int J Pharm Pharma Sci 2010;2(1):146-55.

8. Kar B, Kumar RB, Karmakar I, Dolai N, Bala A, Mazumder UK, et al. Antioxidant and in vitro anti-inflammatory activities of Mimusops elengi leaves. Asian Pac J Trop Biomed 2012;2(2):S976-80.

9. Brown JH, Mackey HK. Inhibition of heat-induced denaturation of serum proteins by mixtures of nonsteroidal anti-inflammatory agents and amino acids. Proc Soc Exp Biol Med 1968;128(1):225-8.

10. Grant NH, Alburn HE, Kryzanauskas C. Stabilization of serum albumin by anti-inflammatory drugs. Biochem Pharmacol 1970;19(3):715-22.

11. Chou CT. The anti-inflammatory effect of Tripterygium wilfordii $\mathrm{F}$ on adjuvant induced paw edema in rats and inflammatory mediator's release. Phytother Res 1997;11(2):152-4.

12. Murugesh N, Vembar S, Damodaran C. Studies on erythrocyte membrane IV: In vitro haemolytic activity of oleander extract. Toxicol Lett 1981;8(1-2):33-8. 